\title{
THE FIRST RECORD OF FACULTATIVE PARASITISM OF MEGASELIA SPP. (DIPTERA: PHORIDAE) IN A HONEYBEE COLONY IN SLOVAKIA
}

\author{
Sabo, R. ${ }^{1}$, Legáth, J. ${ }^{1}$, Staroň, M. ${ }^{2}$, Sabová, L. ${ }^{1}$ \\ ${ }^{1}$ University of Veterinary Medicine and Pharmacy in Košice, Komenského 73, 04181 Košice \\ ${ }^{2}$ National Agricultural and food Centre, Research Institute for Animal Production Nitra \\ Institute of Apiculture Liptovský Hrádok \\ Slovakia
}

rastislav.sabo@uvlf.sk

\section{ABSTRACT}

The current global climate warming trend leads to a shift in animal-habitats northwards. According to the Slovak Hydrometeorological Institute, summer 2018 was extremely hot and long throughout Slovakia. This was probably the fact that resulted in the detection of the presence of Megaselia spp. (Diptera: Phoridae) in one honeybee colony at the University apiary located in Rozhanovce ( $48^{\circ} 46^{\prime} 27.24^{\prime \prime} \mathrm{N}$; $21^{\circ} 22^{\prime} 26.01^{\prime \prime}$ E; eastern Slovakia). The first warning signal after opening the hive was the changed odour. During closer inspection, there were observed small parasitoid phorid larvae that emerged from the sealed bee brood; further examination revealed that the parasitized bee larvae and pupae contained emptied body cavities. Vice-versa, parasitisation was not detected in adult honey bees. Our knowledge of Diptera being responsible for parasitizing (even facultative) the honey bee (Apis mellifera) is still incomplete and needs to be investigated further in more details.

Key words: climate warming; facultative parasitoid; honey bee; Megaselia spp.; phorid fauna

\section{INTRODUCTION}

Honey bees (Apis mellifera L.; Hymenoptera: Apidae) belong to the most important commercial pollinators, providing valuable pollination services worldwide. That is why their good health status is crucial in this role. Global climate change has an impact on the numerous pathogens of honey bees, the interactions with their host-species have not been observed previously [14]. Migration of new pathogens northwards will lead to new encounters with their hosts. It is therefore very important that we understand the current pathogen-bee interactions and prevalence in southern regions of Europe, where the subspecies of A. mellifera, adapted to a hot climate, is native [16].

Our knowledge of Diptera responsible for parasitizing the honey bee is still a challenge for scientists; e.g. the detection of Apocephalus borealis (Diptera: Phoridae) was tied to honey bee parasitoidism, and considered as a potential indirect cause of colony collapse disorder [3].

Megaselia spp. insects belong to Phoridae (Diptera)the family of small, hump-backed flies ( $1-6 \mathrm{~mm}$ lengths) which resemble the fruit flies. They can be recognised according to their escape habit of running rapidly across 
a surface (rather than taking to the wings) and their alternate name "scuttle fly" based on this behaviour [20]. The family Phorid (Diptera) has very heterogeneous larval food requirements and adaptable feeding behaviours such as scavenger, phytophagous and entomophagous [2].

In this paper, we present Megaselia spp. as a legitimate agent of facultative honey bee parasitoidism in Slovakia.

\section{MATERIALS AND METHODS}

During the summer of 2018, four queen-right nuclei prepared on June 4,2018, each consisting of 6 frames (one foundation frame, two store frames plus three brood frames), were maintained in a normal bee-keeping manner in small six-frames hives, with open access to natural food sources. By the regular weekly inspection on July 10, 2018, there was one colony detected as suspicious. By opening the hive, a typical "fetid odour" of old mushrooms was the first warning signal. The strength of the colony was comparable to the other three colonies prepared on the same time, but closer inspection showed, that the suspected nucleus had shifted from the front side of the frames more backwards (Fig. 1) and the sealed brood was left without any bee care. Moreover, there was visibly presented large numbers of small whitish larvae in the brood area (Fig. 2). Capped cells were perforated (Fig. 3) and many larvae were hatching from some of the cells (Fig. 4). The cells in the area where the nucleus had shifted was full of bee eggs (Fig. 5), showing that the nucleus had left the previous brood nest full of parasitoid larvae and tried to set a new nest more backwards on the same frames.

No larvae were detected in the dead or living adult honey bees by necropsy done in situ. After stereomicroscopic examination of the larvae in the laboratory, two specimens of the suspected brood were introduced into a plastic box and maintained at a temperature of $24 \pm 2{ }^{\circ} \mathrm{C}$ and humidity of $60 \%$ (Fig. 6). In 2-3 days after placing the pieces of the comb containing the suspicious brood into plastic containers, larvae pupated and later, after next 7 days emerged as the adult stage. At the beginning, the pupae were whitish and yellowish-brown and in the end of their pupal stage they changed to a dark brown colour.

The dissected bee larvae/pupae were examined using a stereo laboratory zoom-tool on July 11, 2018. On July 21, 2018, the flies that emerged were examined under a ste- reoscopic microscope at a magnification of 5-100 times for the systemic determination using a more recent key to European genera [7] and an updated guide to the identification literature for each genus by the same author [8].

\section{RESULTS AND DISCUSSION}

The examination of the dissected bee larvae and/or pupae respectively under stereo laboratory zoom-tool indicated that parasitoid phorid larvae had fully developed in the bee larvae/pupae body cavities by consuming their internal organs. Inspection of the parasitized bee larvae/pupae remnants revealed the complete destruction of the body cavity structures. In the case of the pupae, the thorax and abdomen had been completely emptied and dismembered. No parasites were detected in the adult bee specimens.

Based on the examination of the emerged adult flies under the stereoscopic light-microscope, the insects were identified as Megaselia spp. (Insecta: Diptera: Phoridae). Due to the difficult taxonomy of the Megaselia spp. genus (the list of Megaselia species is only tentative), the exact species identification was not possible, as the taxonomy of this giant genus counts more than 1400 species worldwide and is still insufficiently known $[8,13]$. The species-richness of the phorid fauna is well known in the Czech Republic but not so well in Slovakia (pers. communication with RNDr. Mocek/entomologist).

Detailed clinical signs of Megaselia rufipes infestation have been documented under controlled conditions in laboratory-reared Hemiptera of the cockroach species [6] and in other insects, such as blowflies (Diptera: Calliphoridae) [1], and Noctuid moths [15]. M. rufipes infestation begins with egg deposition on the abdomen of adult bee and the ensuing embryonic development. After hatching, the first instar larvae penetrate the intersegmental membranes of the abdomen. At completion of the instar life, larvae leave their host in search of suitable pupation sites. While such parasitoid behaviours have often been observed and reported in species of the Megaselia genus, some species of the genus Megaselia are known to beekeepers as cleptoparasites, which are dependent on stored pollen and other organic remains found on the hive bottom [9]. The most common is Megaselia scalaris and has been documented as a scavenger in bee colonies in Spain [11], in Central-Southern Italy [17] and in Cameroon [4] in the last decade. 


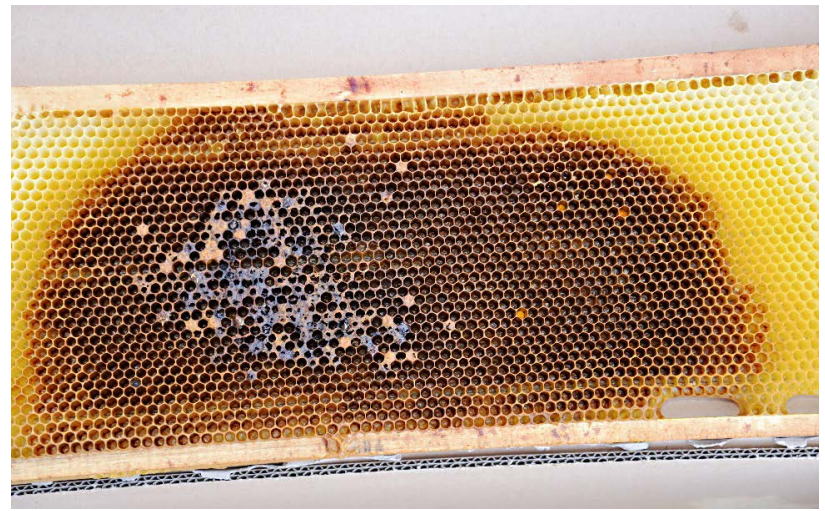

Fig. 1. Suspected frame

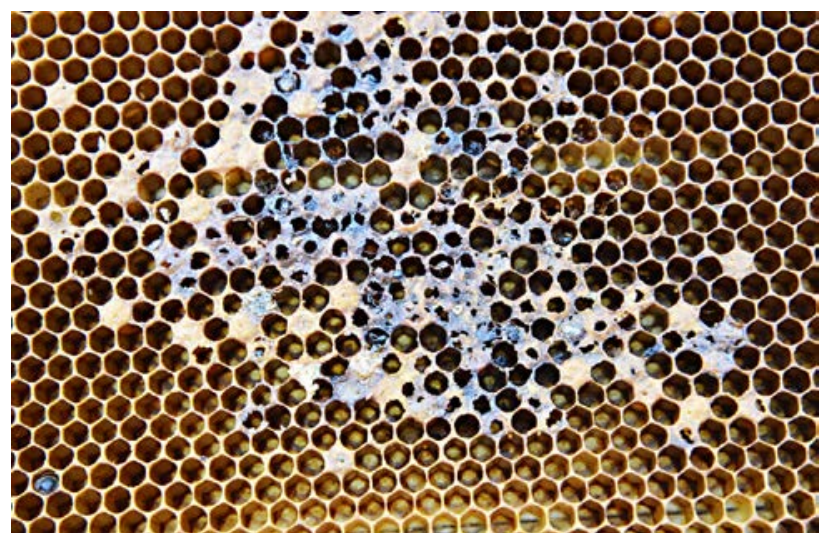

Fig. 3. Perforated capped cells

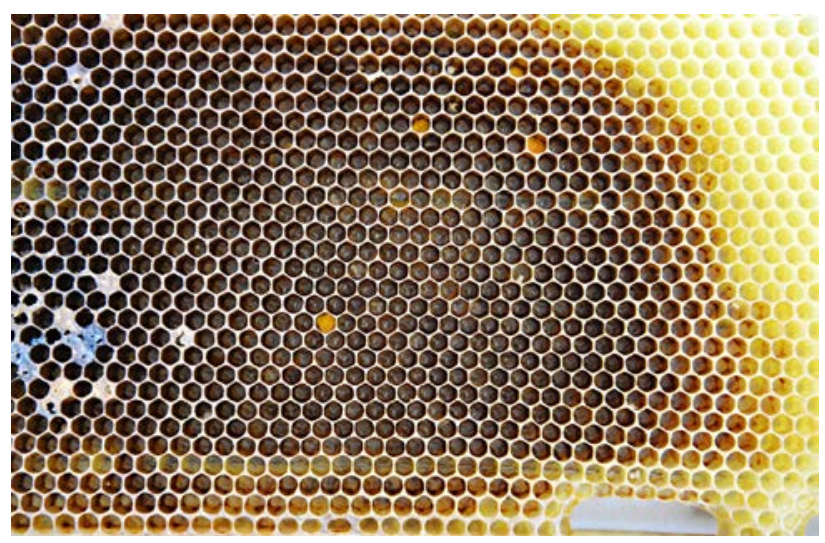

Fig. 5. New nest shifted backwards of the frames (area of fresh laid bee eggs)

Moreover, the presence of Megaselia rufipes and Megaselia praeacuta (both Diptera: Phoridae) were recorded from samples of dead honey bee colonies during 2017 in the Republic of North Macedonia [12]. M. rufipes is suggested to be a facultative parasitoid of $A$. mellifera that exploits the

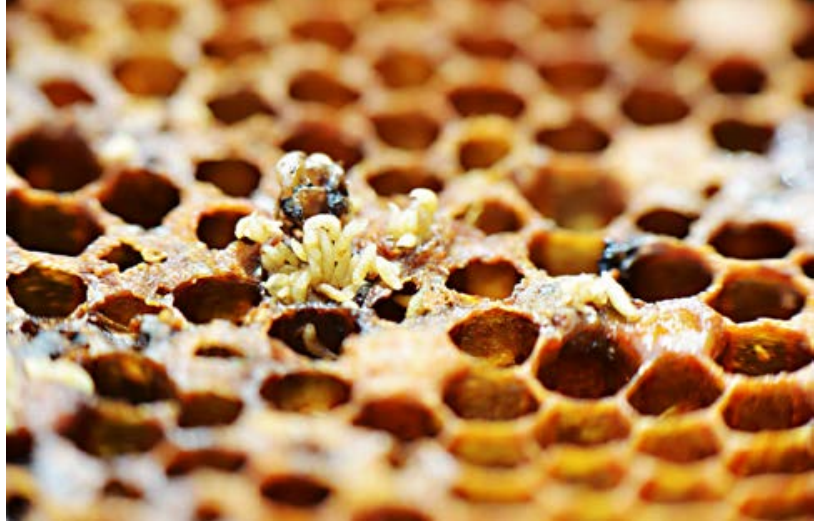

Fig. 2. Small larvae on the brood area

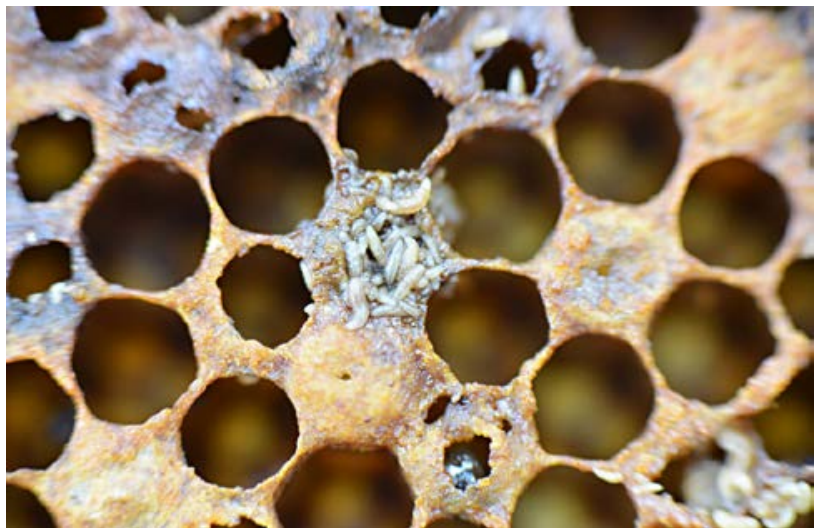

Fig. 4. Hatching larvae from cells

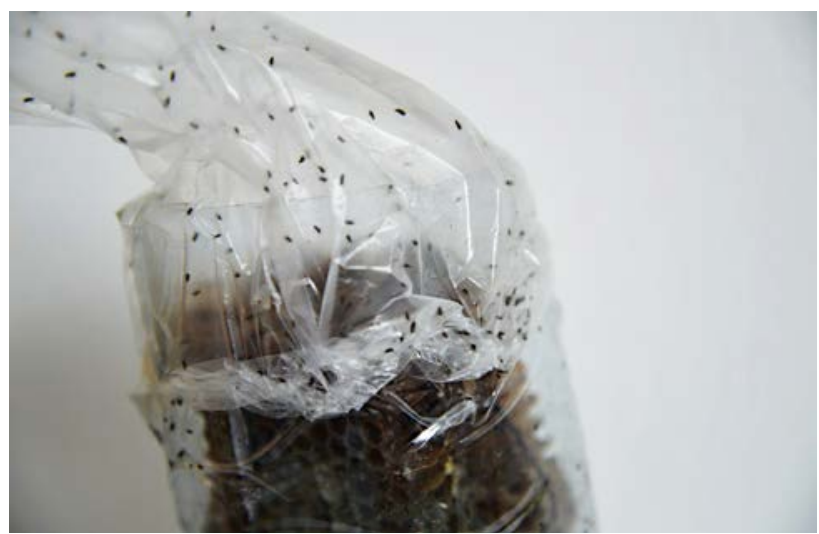

Fig. 6. Hatched adult insects

movement difficulties of deformed-winged bees [10]. Similar behaviours were observed in Megaselia scalaris in both the laboratory cockroach cultures and in the field [18].

Aside from honey bees, the broad host range of these phorid flies also makes them a considerable danger to wild 
pollinators [5]; phorids have also shown an attraction to injured ants $[3,19]$. Phorid larvae Apocephalus borealis discovered in dead honey bees are strongly suspected of colony collapse disorder, despite that it is reported that this parasitoid fly affects bumblebees and wasps [5]. The adult fly lays eggs on the bee's abdomen, later hatch and feed on the bee; affected honeybees show hive abandonment behaviour, leaving their hives at night and dying shortly outside the hive.

Our case showed that Megaselia spp. (Insecta: Diptera: Phoridae) can be considered a facultative parasitoid of A. mellifera. Except for the matter of fact, that this is the first record in central Europe, its detection also opens new scenario in the role of Phoridae in honey bee colony health for the future in this geographical latitude.

\section{CONCLUSIONS}

In this paper, we presented Megaselia spp. (Insecta: Diptera: Phoridae) as a legitimate agent of facultative parasitoidism, recorded for the first time in bee colony in central Europe/Slovakia. As this is the first report, the situation needs to be monitored due to the potential adverse/ negative impact of Megaselia spp. on bee colonies survival in the future.

\section{ACKNOWLEDGEMENTS}

We would like to thank to the entomologist RNDr. Bohuslav Mocek (Department of Natural Sciences, East Bohemian Museum in Hradec Králové, Czech Republic) who is specialised in Diptera-Phoridae, Odonata, for his contribution in insect identification.

Funding was provided by the National Reference Laboratory for Pesticides of University of Veterinary Medicine and Pharmacy in Košice, Slovakia.

\section{REFERENCES}

1. Batista-da-Silva, J. A., 2012: Phoretic association and facultative parasitoidism between Megaselia scalaris and blowflies, under natural conditions. OnLine J. Biol. Sci., 12, 34-37. DOI: 10.3844 /ojbsci.2012.34.37.
2. Brown, B. V., 1996: Review of "scuttle flies: The Phoridae". Proc. Entomol. Soc., Washington, 98, 166-167.

3. Brown, B. V., Feener, D. H. Jr., 1993: Life history and immature stages of Rhyncophoromyia maculineura, an ant-parasitizing phorid fly (Diptera: Phoridae) from Peru. J. Nat. History, 27, 429-434.

4. Cham, D., Fombong, A., Ndegwa, P., Raina, S., 2018: Megaselia scalaris (Diptera: Phoridae), an opportunist parasitoid of honey bees in Cameroon. African Entomol., 26, 1, 254258. DOI: 10.4001/003.026.0254.

5. Core, A., Runckel, C., Ivers, J., Quock, C., Siapno, T., Denault, S., et al., 2012: A new threat to honey bees, the parasitic phorid fly Apocephalus borealis. PLOS ONE, 7, e29639. DOI: 10.1371/journal.pone.0029639.

6. Costa, J., Almeida, C. E., Esperança, G. M., Morales, N., Dos, S., Mallet, J. R., et al., 2007: First record of Megaselia scalaris (Loew) (Diptera: Phoridae) infesting laboratory colonies of Triatoma brasiliensis Neiva (Hemiptera: Reduviidae). Neotrop. Entomol., 36, 6, 987-989. DOI: 10.1590/S1519-566 X2007000600026.

7. Disney, R. H. L., 1998: Family Phoridae. In Papp, L., Darvas, B. (Eds.): Contributions to a Manual of Palaearctic Diptera. Vol. 3. Higher Brachycera. Budapest, Science Herald, $51-79$.

8. Disney, R. H. L., 2003: Revisionary notes on European Phoridae (Diptera). Bonner Zoologisches Beiträge, 50, 293-304.

9. Disney, R. H. L., 2008: Natural history of the scuttle fly, Megaselia scalaris. Annu. Rev. Entomol., 53, 39-60. DOI: 10. 1146/annurev.ento.53.103106.093415.

10. Dutto, M., Ferrazzi, P., 2014: Megaselia rufipes (Diptera: Phoridae): a new cause of facultative parasitoidism in Apis mellifera. J. Apic. Res., 53, 1, 141-145. DOI: 10.3896/ IBRA.1.53.1.15.

11. Fernández, G. P., Alverez, S. C., Moraga, Q. E., 2010: Primeracita de Megaselia scalaris (Loew, 1866), (Diptera: Phoridae) en Apis mellifera iberiensis. ReviewIbero-Latinoam. Parasitology, 69, 72-76.

12. Kiprijanovska, H., Lazarevska, S., Golubovski, M., Uzunov, U., 2018: First report on the presence of Megaselia rufipes (Meigen, 1804) and Megaselia praeacuta (Schmitz, 1919) in honey bee colonies in the Republic of Macedonia, J. Apic. Res., 58, 1, 114-116. DOI: 10.1080/00218839.2018.1501863.

13. Koch, N. M., Fontanarrosa, P., Padro, J., Soto, I. M., 2013: First record of Megaselia scalaris (Loew) (Diptera: Phoridae) infesting laboratory stocks of mantids (Parastagmatoptera tessellate, Saussure). Arthropods, 2, 1-6. 
14. Le Conte, Y., Navajas, M., 2008: Climate change: impact on honey bee populations and diseases. Rev. Sci. Tech., 27, 499-510.

15. McCabe, T. L., 1998: Dipterous parasitoids from adults of moths (Lepidoptera). Entomol. News, 109, 325-328.

16. Menail, A. H., Piot, N., Meeus, I., Smagghe, G., LoucifAyad, W., 2016: Large pathogen screening reveals first report of Megaselia scalaris (Diptera: Phoridae) parasitizing Apis mellifera intermissa (Hymenoptera: Apidae), J. Inverteb. Pathol., 137, 33-37. DOI: 10.1016/j.jip.2016.04.007.

17. Ricchiuti, L., Miranda, M., Venti, R., Bosi, F., Marino, L., Mutinelli, F., 2016: Infestation of Apis mellifera colonies by Megaselia scalaris (Loew, 1866) in Abruzzo and Molise regions,
Central-Southern Italy. J. Apic. Res., 55, 187-192. DOI: 10. 1080/00218839.2016.1196017.

18. Robinson, W. H., 2005: Handbook of Urban Insects and Arachnids. Cambridge University Press, Cambridge, UK, 490 pp.

19. Silveira-Costa, A. J., Moutinho, P. R. S., 1996: Attracting parasitic phorid flies (Diptera: Phoridae) to injured workers of the giant ant Dinoponera gigantea (Hymenoptera: Formicidae). Entomol. News, 107, 93-98.

20. Schmitz, H., 1981: Phoridae. In Lindner, E.: Die Fliegen der Paläarktischen Region. Band IV/7, Part 1, Pemberley Publ., $672 \mathrm{pp}$.

Received September 14, 2020

Accepted October 16, 2020 